\title{
Apartment Houses for Mallards?
}

By W. J. DOUGLAS STEPHEN,

Seasonal Technical Officer, Canadian Wildlife Service

Imagine the surprise on the morning of May 21, 1957 when the author found a Mallard nest in the corner of a barn loft. This barn was on an abandoned farm $11 \frac{1 / 2}{2}$ miles west and 7 miles south of Kindersley, Sask. He was investigating the loft as a potential source of pigeons for retriever training purposes, while helping to conduct a nesting and population study on the Kindersley waterfowl experimential area. The sitraw pile on which the nest was found was about three feet high and 12 feet square in a corner of the loft in the shadow of the loft door. The nest was close to the wall. The hen gained entry to the loft either through this loft door which was six feet high and ten feet wide and twelve feet from the ground, or through a window about 30 inches square which was 10 feet above the loft floor and 22 feet from the ground. The ladder leading to the loft entered near the loft door. The duck under- standably used the window for escape on two occasions when flushed.

On May 27, an unsuccessful attempt was made to capture the hen in order to neck-band, leg-band and weigh her. However, all 11 eggs were just hatching and each of the nestlings was marked with a fingerling tag in the web of the foot or in the patagium of the wing. A banding crew which consisted of Bernie Gollop, Ron Lamont, and the author were unable to wait to sec the exodus of the brood from the barn, but undoubtedly all the chicks made their way out through the oper loft door and fluttered the 12 feet to the ground. Investigation of the barr on June 3 revealed only a used nes and empty egg shells?

The potentialities of apartmen nesting sites in future managemen for waterfowl were discussed by the biologists, but cpinions were dividec by the thought of predatory landlords

\section{Mallard Nesting in Barn at Langenburg}

\section{By STUART HOUSTON, Yorkton}

On Sundiay, May 26, 1957, I drove to the farm of Mr. Frick six and one-half miles north and two miles east of Langenburg to investigate the report of a Mallard duck nesting in a barn.

The nest was in the straw under a manger in an unused barn (Fig. 1).

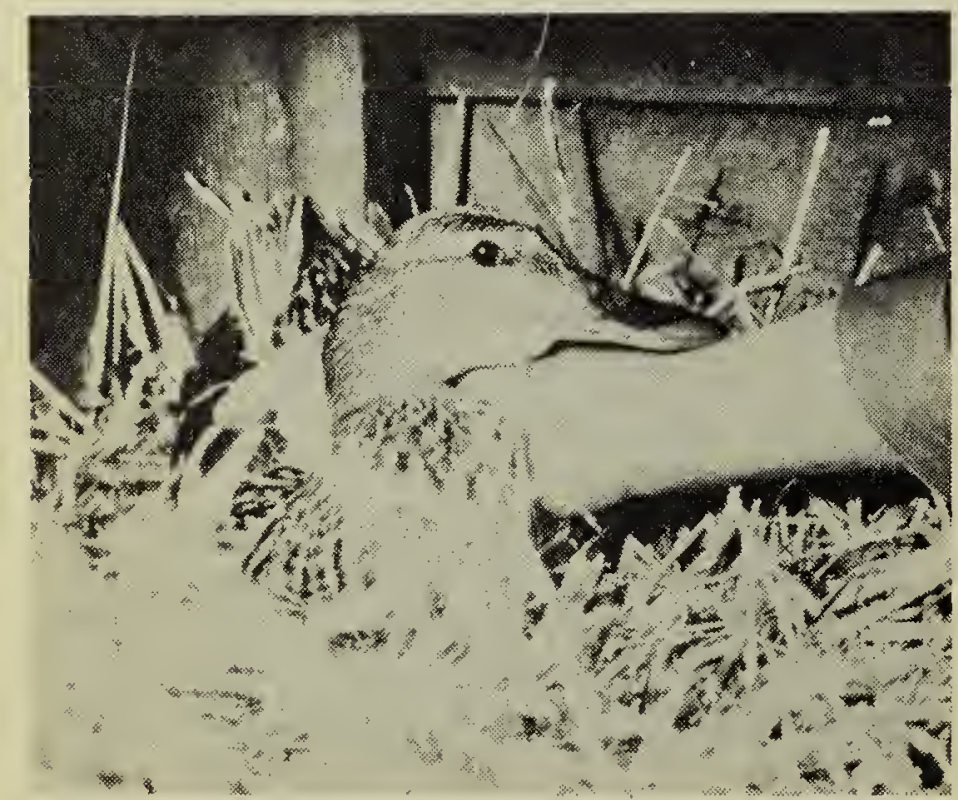

Fig. 1. Mallard duck on nest under manger.
Entrance to the barn had been gaine through the narrow space of si: inches left by the unclosed doo (Fig. 2). The Mallard was "cornered and didn't fly, allowing herself t be photographed at two feet. After wards, she was picked up, bandec and placed back on the nest.

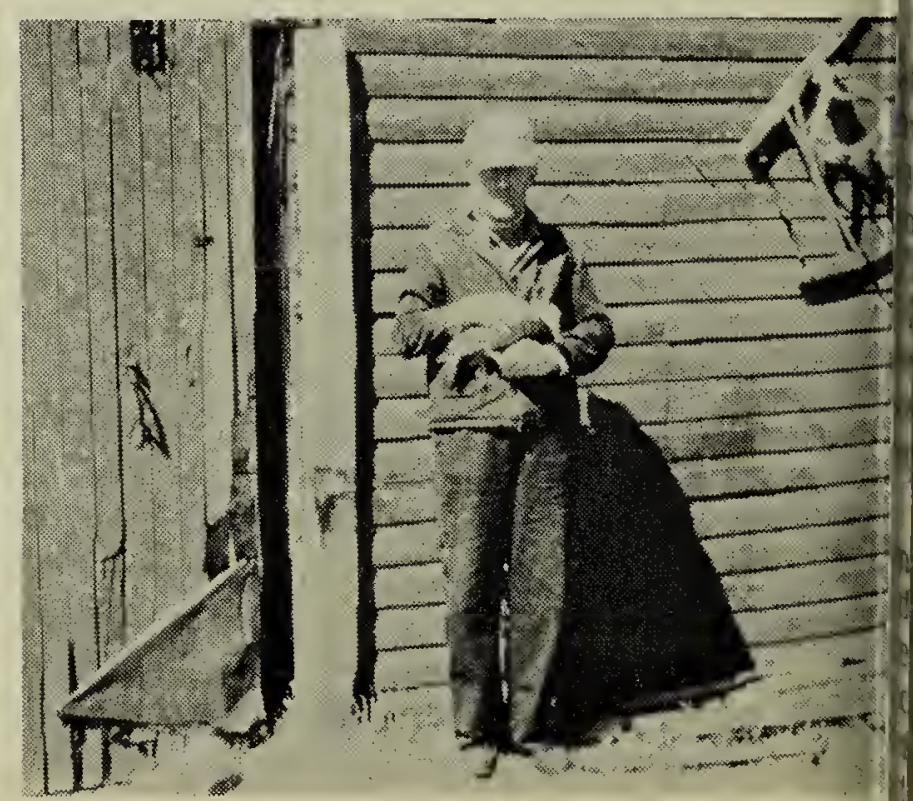

Fig. 2. Unclosed door through which mallas entered barn. 